\title{
Culture as a Factor of Influence on the Management Potential of Modern Organizations
}

\author{
${ }^{1}$ Khanif S. Mullakhmetov, ${ }^{2}$ Ruslan D. Sadriev, ${ }^{3}$ Ekaterina V. Krotkova, ${ }^{4}$ Rustem I. Sharafutdinov \\ 1, 2,3,4 The Branch of Naberezhnye Chelny Institute of Kazan (Volga Region) Federal University \\ Republic of Tatarstan, Naberezhnye Chelny, 68/19 (1/18), 335, 423810 \\ Email:nek_m@rambler.ru, Contact: +79600705088
}

Received: 15th December 2017, Accepted: 20th December 2017, Published: 31st December 2017

\begin{abstract}
The paper deals with the problems of management of Russian companies and suggests to form a strong corporate culture as one of the approaches to their solution. Management potential, as the most important component of the human capital of organizations, is considered as a system of three main subsystems (health, intellect and culture); a brief interpretation of each of them is provided. Based on the results of the study of the influence of corporate culture on the management characteristics of the 10 largest international and Russian companies, the role of cultural instruments as a reserve for improving the efficiency of Russian companies is substantiated, and the directions of work are outlined. The restrictions caused by the characteristics of the management system allow neither using intellectual resources in full, and reduce the adaptability and pace of development of Russian companies and their innovative activity. The authors believe that a strong corporate culture, consistent with the strategy of companies, can become the basis for fundamental qualitative changes in Russian companies.
\end{abstract}

Keywords: Management Potential, Human Capital, Corporate Culture, Innovative Development, Personnel Management

\section{Introduction}

In the 1950s, the first professional associations of managers defined management in terms of "efficiency", "planning", "division of labor", "management", "control", and management as a science had to systematize the accumulated world management experience and develop theory from this position [1, p. 19-26]. Studies of the history of management show that all successful civilizations and famous personalities sought to be more effective, for which they used various methods of planning, organization, motivation and control. [2, 3]. As Frank Arnold writes on the basis of a study of the biography of nearly 60 eminent personalities, "...The secret of successful management lies in the biography of these people: the way they have improved their own productivity is the principles of effective management" [4, P.10]. The author emphasized that effective management is the key to the success not only of individuals, but also of various organizations and society as a whole. The problem of increasing efficiency becomes especially urgent in the emerging "new economy", based on the constant and systematic generation of organizational, technological and product innovations. Scientists identify the role of management in ensuring the competitiveness of organizations. Strategic competitive advantages are formed today at the level of business processes, which effective functioning depends on the quality of management [5, C.7-8].

The researchers emphasize the need for a systematic approach to the problem of effectiveness. Considering productivity as a factor of increasing the efficiency and competitiveness, the scientists of KFU offer integral (multifactor) productivity as a key parameter of competitiveness [5]. Frank Arnold points out that productivity must be considered from the standpoint of the main constituent parts: work, time and capital; he emphasizes the need for paying attention to workers of intellectual labor, since they bring knowledge and innovations to the organization, and use them [4, P.64]. As we can see, in the conditions of the "new economy", knowledge and innovation, carried by personnel, become key factors in improving the efficiency of management facilities.

In today's world, the competitive advantages of the economy and the possibilities for its modernization are largely determined by the human capital accumulated and realized in various areas. Human capital is a diverse and highly complex productive factor that affects the development of the economy and society, including labor force, innovation system, high-performance accumulated knowledge, professional information systems, intellectual and organizational tools, quality of life and intellectual activity that ensure the effective functioning of the human capital [6]. Modern theories of economic growth treat human capital as one of its key factors, since it is human capital that can ensure economic growth not only by increasing labor productivity, but also through the generation and implementation of new ideas and innovations [7].

Today, in the age of innovative development, traditional methods of managing human capital lose their potential and become constraining factors that reduce the effectiveness of management. This 
requires the creation of a management system where the managerial potential, capable of providing adaptability and flexibility of management systems, a qualitative implementation of the conceived, the balance and harmonization of various social forces in the collectives, and the formation of healthy companies should play a decisive role.

\section{Methods}

The idea of human capital in any of its forms has been considered in many works; many of its definitions and interpretations have been worked out. G. Becker considered human capital as a set of skills, knowledge and abilities of a person. He defined that "human capital is formed by investing in people, including education, training in production, health care costs, migration and information retrieval." 7 Human capital, by $\mathrm{T}$. Schulz's definition, is a person's valuable qualities, which can be strengthened by appropriate investments [8]. E. Dolan and J. Lindsey understand human capital as capital in the form of mental abilities acquired either through formal learning and education, or through practical experience [9].

There is no single opinion on the concept of human capital among Russian researchers.

Most often, the authors define health capital and education capital. In addition, there are capitals related to culture, as well as professional activities of workers [10].

In the context of our study, we consider the management potential as an essential component of human capital.

In our opinion, managerial potential of a manager is a system of interrelated and interdependent human abilities (health, intellect, culture) that are necessary in the management of socio-economic systems and transformed through managerial processes into a positive effect in the form of various resources. The state of managerial potential is most clearly reflected in the process of development, adoption and implementation of management decisions (MD). Given the multi-valued and multifaceted nature of this category, MD can be viewed as the result of management of an organization that has an internal potential (structure, processes, managerial and corporate culture, people). The competence of management is determined, firstly, by the ability to take thorough MD and, secondly, the ability to organize their implementation, which requires all the components of the management potential (health, intellect and culture) [11].

The managerial potential of the organization is ensured through interaction of managers that have their personal managerial potential in the management processes for the formation and implementation of the organization's goals and can be considered as the result of the interaction of individual managers and management units.
Accordingly, the managerial potential of the organization's management can be considered as a capital determined by two factors: first, the level of managers that determines the aggregate managerial potential and, secondly, the nature of the interaction of managers and management units of different levels in the management system, which determines the practical implementation of the managerial potential. The total potential of managers, based on the characteristics of the organization's management system, can be implemented either in full or in part, as well as can increase or decrease due to systemic effects. Trends and the dynamics of changes are mainly determined by the level of development of the balance of formal and informal institutions, vertical and horizontal links in the management system, which ultimately establish a stability and flexibility relationship in the management system. Thus, the managerial potential of an organization is the sum of the potentials of managers of an organization multiplied by the organizational factors, which, depending on the characteristics of the management system, may be more or less than unity.

\section{Results}

To determine the influence of the group of factors "culture" on the managerial potential, we will analyze the practice of applying corporate culture in the management system of domestic and foreign companies in the petrochemical and automotive industries (Shell, British Petroleum, Toyota, Rosneft, Gazprom, Tatneft, Nizhnekamskneftekhim, Kazanorgsintez, Ammonii, and KAMAZ).

Based on the study of data on open sources, it can be argued that companies are focused on shaping the external level of the corporate culture. This level is visible and presents no difficulty to collect data thereon from open sources.

Many indicators that characterize the level of values of corporate culture have their gaps. This may be the result of a lack of work in companies, or is associated with the difficulties of collecting data on this invisible level of corporate culture. Final conclusions about the level of development of corporate culture in companies at the level of values can be made only after conducting field research.

The main mechanisms of corporate culture in management are revealed. Characteristics of the corporate culture may:

- influence the management of personnel, namely, determine the systems of acceptance and dismissal, encouragement and punishment, improve the qualifications of employees, promote workers in their service bot horizontally and vertically. Corporate culture in most of the companies surveyed has only a partial effect on personnel management. It was found out that in all companies there is a system of professional development of employees, 
and, with rare exceptions, systems of acceptance and promotion of employees. The remaining elements of the personnel management system are either insufficiently developed or completely absent; - promote the socialization of workers, create working conditions; these elements are well developed in all companies studied;

- promote the development of horizontal, vertical, as well as direct and reverse links in the management system. It can be concluded that in the vast majority of companies, corporate culture has little effect on the establishment of types of links;

- influence the characteristics of the management system (the priority of the social and humanitarian component, the participation of workers in the adoption of $\mathrm{MD}$, the reduction of management levels, the rapid response to workers' requests, the removal of barriers between management and the subordinate). Most companies have limited impact of the characteristics of the corporate culture on the characteristics of the management system.

It can be concluded that only in Toyota its corporate culture plays an essential role in the management system. It has well-developed democratic management principles and "soft" forms of control, based on the principles of self-management and selfcontrol. The analyzed management procedures in the company are standardized and clearly defined. We unfortunately failed to collect an extensive information on other companies in open sources.

\section{Discussion}

The cultural component of management in general and the managerial potential in particular is universally recognized. Lorry Mullins points out that despite the fact that the role, powers and responsibilities of managers vary depending on the nature of the organization, the managers of any status contribute to the development of the culture of the organization; managers play a key role in the culture implementation [12]. Edgar Shane believes that the management and culture of the organization are inseparable from each other and consistently affect the perceptions and attitudes of hired workers [13].

Culture helps reduce complexity and uncertainty in management. It correlates internal values and their external manifestations, and also makes possible the process of MD adoption, coordination and control [14]. Culture, that is, the set of representations, beliefs, values and norms that determine how everything is going on here, is a powerful monitoring system, since it affects not only open organizational behavior, but also its hidden shadow side [15].

The formation of culture is undoubtedly necessary for the effective operation of the organization; strong culture, consistent with the strategy, becomes a precondition for improving the efficiency of the management facility. Heller, according to the results of a study of the largest European companies, notes that the culture of the organization is directly related to the effectiveness of its activities [16].

Our research has shown that the state of the economy, the efficiency of companies and their management has a direct strong dependence on the level of development of the corporate culture, on the extent to which the tools are used in various management subsystems.

\section{Summary}

As studies show, interest in corporate culture, which was manifested theoretically in the writings of representatives of the behavioral school of management (40s of the XX century), and reached its peak by the $1980 \mathrm{~s}$, is a conscious necessity, the creation of a strong corporate culture, consistent with the strategy of companies - a precondition for effective management, survival and competitiveness of companies in the long term [17]. The trends and dynamics of development of Japan, which gained economic superiority over America, and now has an unconditional technological superiority, has gradually led to the understanding that technology, structure, automation and robotization of processes are not the only factors determining economic progress. The result of studies aimed at establishing a correlation between the culture of the organization and its effectiveness showed that it is impossible to explain economic growth only by the actions of the "economic person" [1, p. 246-247]. Recognition of the cultural component of management caused the need to study the corporate culture of organizations and people as the main factor of its development. Intellectual capital is a management concept that attracted much attention in the second half of the 1990s. Its fundamental idea is that the organization includes values that cannot be expressed with the help of traditional methods. The totality of such values was called intellectual capital and, together with the residual value of the organization's fixed capital, was its total value. Human capital is the result of the interaction of the organization's personnel in the main, auxiliary and managerial processes. An important component of the human capital of the organization is the managerial potential, which we consider as a system of interconnected and interdependent groups of managerial abilities (health, intellect and culture), being transformed through management processes into a positive effect.

The study of corporate culture of the 10 largest domestic and foreign companies confirms the general trend: the effectiveness of management in general, the managerial potential of organizations and, accordingly, the efficiency of companies' activities directly depend on the level of corporate culture development, on how far the culture tools are used in various management subsystems. 


\section{Conclusions}

The evolution of the development of corporate culture in the management system in the second half of the XX century shows that the concept of human capital, intangible assets accounting, the abandonment of the priority of financial indicators in assessing the performance of companies, will remain the main trends in management development in the XXI century. The problem of balance of management stability and flexibility as a condition of survival and competitiveness of companies in today's business environment cannot be successfully solved without taking into account the cultural component in the management system.

As the studies showed, the possibility of strengthening managerial capacity through the tools of corporate culture at Russian enterprises is poorly applied.

The results of the study of the implementation status of lean principles in Russian enterprises showed that a practiced management style - the ignoring of the corporate culture as a management mechanism - is the main obstacle to the introduction of lean production philosophy [18].

The trend of the development of society and economy poses new demands for the management of social and economic systems; the qualitative transformation of human capital pushes management to "softly regulate" the actions and behavior of people on the principles of self-management and self-control based on a developed corporate culture.

\section{Acknowledgements}

The work is performed according to the Russian Government Program of Competitive Growth of Kazan Federal University.

\section{References}

1. Cummings S. Reconstruction of the strategy / trans. from English. - Kh.: Publishing House "Gumanitarnyi Tsentr", 2010. - p. 560.

2. Classics of management / Ed. M. Warner / Trans. from English. - St. Petersburg: Piter, 2001. - p. 1168.

3. Marshev V.I. History of administrative thought: a textbook. - M.: Infra-M, 2005. - p. 731.

4. Frank Arnold. Management: learning from experts: trans. from Germ. - Rostov-on-Don: Fenix, 2012. - p. 333.

5. Gafurov I.R., Safiullin M.R., Safiullin A.R. Analysis of structural discontinuities in the competitiveness of the petrochemical cluster of the Republic of Tatarstan. - Kazan; Kazan University, 2012. - p. 284.

6. Nevretdinova M.V. (2015). Innovative approaches to the management of human capital. Economics and Entrepreneurship. 5 (1). - Pp. 550554.
7. Becker G.S. (2003). Human behavior: an economic approach. Selected works on economic theory, GUVShE, p. 671.

8. Schultz, T. (1961) Investment in Human Capital. The American Economic Review, 1, 38-56

9. Dolan E., Lindsay, J. (1992) Market: microeconomic model, Autocomp, p. 477.

10. Sharafutdinov RI, Gerasimov VO, Yagudina OV, Dmitrieva IS, Pavlov SV, Akhmetshin EM Research of Human Capital in The View of Labor Potential of Staff: National Companies Case Study // Proceedings of the 29th International Business Information Management Association Conference Education Excellence and Innovation Management through Vision 2020: From Regional Development Sustainability to Global Economic Growth. ViennaAustria: IBIMA, 2017. P. 839-852.

11. Mullakhmetov K. (2016). Control in the system of managerial decisions procedures: A conceptual view. Problems and Perspectives in Management, 14(3), 64-76. doi:10.21511/ppm.14(3-1).2016.07

12. Laurie Mullins. Management and the organizational behavior, 2003, 1039 p., p. 361.

13. Schein, E.H. Organisation Culture and Leadership, jossey Bass (1985)

14. GormanL. Corporate Culture - Why Managers Should be interested, Leadership and organization Development journal, vol 8, no.5, 1987, pp 3-9

15. Egan, G. The Shadow side «Management Today», September, 1993

16. Heler, R. In Search of European Excellence, Harper Collins Business (1997), p. 229

17. Mullakhmetov Kh.Sh. Corporate culture in the management system // Society and Economy, No.11. - 2016. - Pp. 41-53.

18. Sadriev R. D., Mullakhmetov K. S., Krotkova E. V. \& Gabaidullina L. A. (2016). Introduction of Lean Production at Russian Enterprises: Perspectives and Problems. International Journal of Economics and Financial Issues. 6(S8), 39-48. 